\title{
Strategies for Mitigating Climate Change Effect on Honey Bee Productivity in Southern Nigeria
}

\author{
Maria, Bisong Onabe ${ }^{1}$, Ajigo Ikutal ${ }^{1}$, Agbachom, Emmanuel Edet ${ }^{2}$ \\ and Godwin Michael $\mathrm{Ubi}^{3^{*}}$ \\ ${ }^{1}$ Department of Vocational Education, University of Calabar, Calabar, Nigeria. \\ ${ }^{2}$ Department of Agricultural Economics, University of Calabar, Calabar Nigeria. \\ ${ }^{3}$ Department of Genetics and Biotechnology, University of Calabar, Calabar, Nigeria.
}

Authors' contributions

This work was carried out in collaboration among all authors. Authors MBO, Al and GMU designed the study, Author GMU performed the statistical analysis, Author MBO wrote the protocol, Authors Al and MBO wrote the first draft of the manuscript. Authors MBO and GMU managed the analyses of the study. Author Al managed the literature searches. All authors read and approved the final manuscript.

Article Information

DOI: 10.9734/ARRB/2019/v33i330123

Editor(s):

(1) Prof. Jean-Marie Exbrayat, Université Catholique de Lyon, France. (2) Ibrahim Farah, Professor of Biology/Environmental Health and Director of Animal Core Facilities, Department of Biology, Jackson State University, Mississippi, USA.

(3) Paola Angelini, Department of Applied Biology, University of Perugia, Perugia, Italy. Reviewers:

(1) Atilla Akbaba, İzmir Katip Celebi University, Turkey. (2) Cookey Aloma Tammy, University of Uyo Akwa Ibom State, Nigeria. Complete Peer review History: https://sdiarticle4.com/review-history/51528

Original Research Article

Received 03 July 2019

Accepted 17 September 2019

Published 22 October 2019

\begin{abstract}
This study aimed at determining the educational requirement of Beekeepers in mitigating Climate Change Effects on bee honey production in Obudu Local Government Area of Cross River State, Nigeria. The survey research design was used in achieving this. To adequately and appropriately execute the project three objectives were formulated. From these objectives, research questions were generated and hypotheses formulated accordingly to guide data gathering and analysis. The instrument for data gathering was a four point close ended questionnaire from which 150 farmers and 50 extension agents were selected to respond to items in the questionnaire using the census approach. Data collected from their responses were subjected to two forms of descriptive analysis. The first was percentage descriptive analysis which was used to $x$-ray the biodata. Second, mean and standard deviation were used to treat the research questions. The third method used is the independent t-test on the three man hypothesis of the study. The result of the analysis warranted
\end{abstract}


the rejection of the three null hypotheses tested at 0.05 level of significance with 198 degrees of freedom using 1.96 as the critical t-value. It was found out that ecological practices of farmers contribute to climate change, climate change has impacted negatively on bee honey production, and farmers should be educated through agricultural extension education in order to become conscious of their practices on natural resources and mitigate climate change effects in bee honey production.

Keywords: Climate change; effect; mitigation strategies; honey bee productivity.

\section{INTRODUCTION}

\subsection{Background to the Study}

Climate change is a significant and lashing variation in the statistical distribution of weather patterns over periods ranging from decades to millions of years. It is a change in average weather condition that is more for fewer extreme weather events such as floods, droughts, and heat waves. In the opinion of [1] climate change refers to a variation in climate attributed directly or indirectly to human activities which alter the composition of the global atmosphere in addition to natural climate variability observed over comparable time period. Climate change has threatened the long-term capacity for food production through increased soil erosion and reduced soil fertility which impact somewhat negatively on bee farming and production.

Climate change is caused as a result of natural factors like alterations in the earth's path around the sun, volcanic activity and fluctuations within the climate system. Moreso, humans are having an increasing influence on the climate by burning fossil fuels and cutting down rain forests. Commenting on the causes of climate variability, [2] observed that the energy from the sun warms up the earth, the planet radiates some of the heat back out towards space. [3] posited that certain gases in the atmosphere such as carbon dioxide, water vapors, methane, nitrous oxide, and chlorofluorocarbons acts like the glass in the green house that allows the energy from the sun to get in and prevent the escape of heat. Deforestation releases immense amount of carbon dioxide which is absorbed by trees into the atmosphere and causes greenhouse effects. Therefore, there is need to limit these effects in order to promote sustainability in agriculture production, particularly bee farming.

The certainty of increased need for food (including honey) to feed the large population and the uncertainty of the short-term and longterm impacts of climate change on agricultural production system has become a societal problem. However, to enhance effective and extreme weather events, bee beekeepers need to indulge in activities that will positively increase climatic conditions, which allows the right atmosphere congenial to bee increase and fecundity [4].

IPCC [5] observed that increased organic matter translate into moisture available to the root plant and more soluble nutrients in the root zone. Increasing soil organic matter to a large extent help beekeepers avoid the risks associated with climate change and helps in the maintenance of soil structure.

In Obudu Local Government Area, climate related hazard has forced agricultural activities to low and have manifested into ecological problems such as flood, severe windstorms, soil erosion, and excessive rise in temperature, among others. IPCC [6] had asserted that changes in climate pattern and quantity of rainfalls as well as other climate parameters such as drought and relative humidity have impact on the lives of beekeepers and other vulnerable groups in the area. The effect of climate change on agricultural production, particularly bee farming is endangered to level that food security is threatened in the study area [7].

The intergovernmental panel on climate change [8] affirmed that the livelihoods of rural beekeepers are at high risk due to the extreme climate induced events. Furthermore, bee beekeepers are facing challenges as their products get reduced at certain seasons of the year (during extreme cold weather) in this area. It is against this background that the researcher intends to determine the educational requirements of beekeepers for mitigating climate change effects on bee honey production.

\section{MATERIALS AND METHODS}

\subsection{Research Design}

This study adopted the survey design. This choice was appropriate because the study sought to fine out the educational requirements of farming in mitigating climate change effect in 
bee honey production in Obudu Local Government Area of Cross River State. Survey design as one which a group of people or items are studied by collecting and analyzing data from a few people or items considered being a good representative of the entire group. The design enable the researcher to examine the educational requirements in mitigating climate change effects in bee honey production of Cross River State. Thomas et al. [9] further said that survey is a form of planned collection of data for the purpose of description. It also allows for the use of questionnaire. Survey design was used because each step in this study was meticulously preceded with consideration for the large plan and purpose of the study. More so, this design allowed for influence and generalization.

\subsection{Area of the Study}

The study covered Obudu Local Government Area of Cross River State. It is one of the eighteen (18) Local Government Area state. The study area is located in the northern part of the state and the language spoken by the people of Obudu is known as "BETTE". Obudu Local Government Area is located on $6^{0} 66^{1} \mathrm{~N}$ of the equator and longitude $9^{0} 17^{1}$ East of the Greenwich meridian. The study area is bounded to the north by Vandeikya local government area of Benue State, to the south by Mbube in Ogoja Local Government Area, to east by Obanliku Local Government Area and to the west by Bekwarra local government area respectively [10].

The study area has a land mass of $520 \mathrm{~km}^{2}$. The people are predominantly beekeepers and engage mostly in subsistence agriculture. Obudu is located in the tropical rain forest belt with considerable amount of rainfall, which span between April and October each year. This characterizes the types of crops grown in the study. This includes yam, cassava, maize, okra, melon, vegetable, cash crops like oil palm, banana/plantain among others.

Obudu Local Government Area is blessed with abundant natural resources including mountain, hill, fertile land, water resources and a unique climate. The people also engage in livestock farming at commercial level. The people have a very rich culture heritage characterize by colorful festival and beautiful dances [11].

\subsection{Population of the Study}

The targeted population for this study was 200 . This comprised of 150 registered Bee Keepers and 50 extension agents obtained from Cross River State Agricultural Development Program (CRADP).

\subsection{Sampling Technique}

The census approach was used as the population was small and manageable by the researcher. In the opinion of [12] a small population is appropriate because data collection would be faster. It will also minimize bias and simplifies analysis of results.

\subsection{Sample}

The entire population was used in this study because it was small and manageable by the researcher.

\subsection{Instrumentation}

The instrumentation for data collection was a structured questionnaire designed to collect information from the respondents. The questionnaire was divided into two parts. PART 1 Consist of one section (A), while PART 2 consist of three sections $(A-C)$

Part 1: Section A was structured to obtain personal data of the respondents

Part 2: Section A was structured to elicit response on ecological practices of beekeepers that contribute to climate change.

Section B was structured to elicit response on climate change and bee honey production.

Section $\mathrm{C}$ was structured to obtain information on the educational requirement of beekeepers in mitigating climate change effects in bee honey production.

\subsection{Validity of the Instrument}

The questionnaire was validated by two experts. The two experts are from Department of Vocational Education in University of Calabar. They were given a copy of the questionnaire each and requested to read the competency item and develop the final questionnaire for the collection of data for the study.

\subsection{Procedure for Data Collection}

The node of collecting data was through the use of a structured questionnaire. The beekeepers 
were intimated in advance about the exercise. The respondents were served the instrument and retrieved accordingly.

\subsection{Procedure for Data Preparation and Coding}

Data obtained for the study was coded by assigning numerical values to every response to items in the questionnaire. For positively worded items, strongly agree (SA) was awarded 4 points, Agree (A) 3, Disagree (D) 2 and strongly disagree (SD) 1. The reverse scoring was done for the negatively worded items in the questionnaire.

\subsection{Procedure for Data Analysis}

The data collection from the administration of the questionnaire were analyzed using mean and standard deviation to answer the research question while independent $\mathrm{t}$-test was used to test the hypothesis at 0.05 level of significance. The cut -off point was 2.50 , items that recorded while those with mean and score of less 2.50 were taken as disagreed.

\section{RESULTS}

\subsection{Percentage Distributive Analysis of Data}

Table 1 shows that among the 150 registered beekeepers, 90 percent were males while 60 or 40 percent were females. Also, 40 of 50 extension agents were males. In all, the males were 130 (or 65 percent) while the females were 70 (or 35 percent).

Table 2 shows that not less than 165 or $(82.5 \%)$ of the beekeepers were married. A paltry 22 (or $11 \%)$ were either separated or divorced. However, 13 or $(6.5 \%)$ of the respondents claimed they were yet to marry.

Table 3 shows a ratio of One Extension agent to three registered Beekeepers (1:3).

\section{Analysis of research questions using mean} $(x)$ and standard deviation (z)

\section{Research Question 1:}

What are the ecological practices of beekeepers that contribute to climate change? To provide answers to this question, structured questionnaire items on ecological practices of beekeepers that could contribute to climate change were presented to the respondents to indicate how often these practices are carried out in the study area. Their responses are presented in Table 4 as follows.

Table 4 provides the mean ratings of respondents of ecological practices of bee keepers in the study area. The data shows that the five isolated items for this section of the study recorded mean ratings ranging from 2.67 to 3.32 which were above the cut-off point of 2.50 on a four point scale implying that beekeepers are often involved in these practices that could contribute to climate change.

Table 1. Age distribution of respondents

\begin{tabular}{llllllll}
\hline S/N & Sex & \multicolumn{4}{c}{ Respondent } & \multicolumn{2}{c}{ Total } \\
\cline { 3 - 6 } & & \multicolumn{2}{c}{ Registered beekeepers } & \multicolumn{2}{c}{ Extension agent } & NO. & \% \\
\cline { 3 - 6 } & & NO. & NO. & \% & & \\
\hline 1. & Male & 90 & 60 & 40 & 80 & 130 & 65 \\
2. & Female & 60 & 40 & 10 & 20 & 70 & 35 \\
& Total & $\mathbf{1 5 0}$ & $\mathbf{1 0 0}$ & $\mathbf{5 0}$ & $\mathbf{1 0 0}$ & $\mathbf{2 0 0}$ & $\mathbf{1 0 0}$ \\
\hline
\end{tabular}

Table 2. Distribution of respondents by marital status

\begin{tabular}{llllllll}
\hline $\mathbf{S} / \mathbf{N}$ & $\begin{array}{l}\text { Marital } \\
\text { status }\end{array}$ & \multicolumn{2}{c}{ Registered beekeepers } & \multicolumn{2}{c}{ Extension agents } & \multicolumn{2}{c}{ Total } \\
\cline { 2 - 8 } & NO. & \% & NO. & \% & NO. & \% \\
\hline 1. & Single & 8 & 5.3 & 5 & 10.0 & 13 & 6.5 \\
2. & Married & 125 & 83.4 & 40 & 80.0 & 165 & 82.5 \\
3. & Separated & 5 & 3.3 & 3 & 6.0 & 8 & 4.0 \\
4. & Divorced & 12 & 8.0 & 2 & 4.0 & 14 & 7.0 \\
& Total & $\mathbf{1 5 0}$ & $\mathbf{1 0 0 . 0}$ & $\mathbf{5 0}$ & $\mathbf{1 0 0 . 0}$ & $\mathbf{2 0 0}$ & $\mathbf{1 0 0 . 0}$ \\
\hline
\end{tabular}


Table 3. Distribution of respondents by type

\begin{tabular}{llllll}
\hline S/N & Type of respondent & \multicolumn{2}{c}{ Number } & Total & $\%$ \\
\cline { 3 - 4 } & & Male & Female & & \\
\hline 1. & Registered Beekeepers & 90 & 60 & 150 & 75 \\
2. & Extension Agents & 40 & 10 & 50 & 25 \\
& & 130 & 70 & 200 & 100 \\
\hline
\end{tabular}

Table 4. Mean ratings of respondents on the ecological practices that could contribute to climate change

\begin{tabular}{lllll}
\hline S/n & Item description & $\mathbf{X}$ & SD & Remarks \\
\hline 1 & Cutting down of trees & 3.32 & 0.61 & Often \\
2 & Burning of bush for farm purposes & 3.03 & 0.82 & Often \\
3 & Excess of stumping of trees & 2.82 & 0.70 & Often \\
4 & Use of agro-chemicals that pollute the eco system & 2.67 & 0.66 & Often \\
5 & Cultivation of farmlands using inorganic manure & 3.26 & 0.63 & Often \\
\hline \multicolumn{2}{r}{$X=$ mean, SD = standard deviation } \\
\hline
\end{tabular}

Similarly, data on standard deviation ranged from 0.61 to 0.82 which indicates that respondents were not too far from the mean in their responses.

\section{Research Question 2:}

What is the impact of climate change on bee honey production? To provide answers to this question, structured questionnaire items on impact of climate change on agricultural production were presented to the respondents to indicate their level of agreement or disagreement on isolated items in the study area. Their responses are presented in Table 5.

Table 5 presents the mean ratings of respondents on the impacts of climate change on bee honey production. The table shows that the five isolated items recorded mean ratings between 2.77 and 3.28 which are above 2.50 cut-off point on a four point scale. The result shows that the five items are perceived by respondents as impacts of climate change on agricultural production. The standard deviation ranged from 0.55 to 0.92 which revealed that respondents were not too far from the mean and each other in their responses.

\section{Research Question 3:}

What are the educational requirements of beekeepers for mitigating climate change effects on crop production? To provide answers to this question, structured questionnaire items on educational requirements of beekeepers for mitigating climate change effects on crop production were presented to the respondents to indicate whether there are required or not. Their responses are presented in Table 6.

Table 6 presents the mean ratings of respondents on the educational requirements of beekeepers for mitigating climate change effects in bee honey production. The table shows that the five isolated items recorded mean ratings between 2.98 and 3.33 which are above 2.50 cut-off point on a four point scale. The result shows that beekeepers required education on the five isolated items in order to mitigate climate change effects on bee honey production.

The standard deviation ranged from 0.57 to 0.80 which revealed that respondents were not too far from the mean and each other in their responses.

Table 5. Mean ratings of respondents on the impacts of climate change on bee honey production

\begin{tabular}{lllll}
\hline S/n & Item description & $\mathbf{X}$ & SD & Remarks \\
\hline 1 & Effect of prolonged rainfall does not encourage honey production & 2.88 & 0.71 & Agree \\
2 & Negative effect of temperature on honey production & 3.22 & 0.64 & Agree \\
3 & Low honey production during the rain & 3.28 & 0.99 & Agree \\
4 & Poor hive colonization of hives by bees during wet period & 2.77 & 0.92 & Agree \\
5 & Climate change bee habitat for colonization & 3.01 & 0.55 & Agree \\
\hline
\end{tabular}

$$
X=\text { mean, } S D=\text { standard deviation }
$$


Table 6. Mean ratings of respondents on educational requirements of beekeepers for mitigating climate change effects on bee honey production

\begin{tabular}{lllll}
\hline S/n & Item description & $\mathbf{X}$ & SD & Remarks \\
\hline 1 & Seminars & 3.40 & 0.80 & Required \\
2 & Conferences & 3.33 & 0.72 & Required \\
3 & Extension services & 3.10 & 0.58 & Required \\
4 & Workshops & 2.98 & 0.60 & Required \\
5 & Formal education & 3.00 & 0.57 & Agree \\
\hline
\end{tabular}

\subsection{Test of Hypothesis}

Hypothesis one:

The hypothesis states that there is no significant difference in the mean ratings of registered beekeepers and extension agents on ecological practices that could contribute to climate change. To test the hypothesis, independent t-test statistics was employed and the result is presented in Table 7.

Data on Table 7 revealed a calculated $t$-value of 0.94 which was less than table value of 1.960 at 0.05 level of significance and 198 degree of freedom. Since the calculated t-value was less than table value, the null hypothesis was upheld with the alternate hypothesis rejected. With this result, both respondents agreed that beekeepers are often involved in the isolated ecological practices which fuel climate change effects in the study area.

\section{Hypothesis two:}

The hypothesis states that there is no significant difference in the mean ratings of registered beekeepers and extension agents on the impacts of climate change on agricultural production. To test the hypothesis, independent t-test statistic was employed and the result is presented in Table 8.

Data on Table 8 revealed a calculated t-value of 1.16 which was less than table value of 1.960 at 0.05 level of significance and 198 degree of freedom. Since the calculated t-value was less than table value, the null hypothesis was upheld while the alternate hypothesis was rejected. With this result, both respondents agreed that climate change has impacted on agricultural production in the study area.

\section{Hypothesis three:}

The hypothesis states that there is no significant difference in the mean ratings of registered beekeepers and extension agents on the educational requirements of beekeepers for mitigating climate change effects on bee honey production. To test the hypothesis, independent t-test statistic was employed and the result is presented in Table 9.

Data on Table 9 revealed a calculated t-value of 0.32 which was less than table value of 1.960 at 0.05 level of significance and 198 degree of

Table 7. Independent t-test analysis to compare the mean ratings of registered beekeepers and extension agents on ecological practices of beekeepers that contribute to climate change

\begin{tabular}{|c|c|c|c|c|c|}
\hline Group/variable & $\mathbf{N}$ & $\mathbf{X}$ & SD & t-cal & Remarks \\
\hline Registered beekeepers & 150 & 16.50 & 4.05 & & \\
\hline Extension agent & 50 & 16.33 & 3.85 & & \\
\hline
\end{tabular}

Table 8. Independent t-test analysis to compare the mean ratings of registered crop beekeepers and extension agents on the impacts of climate change on agricultural production

\begin{tabular}{|c|c|c|c|c|c|}
\hline \multirow{3}{*}{$\begin{array}{l}\text { Group/variable } \\
\text { Registered crop beekeepers }\end{array}$} & $\mathbf{N}$ & $\mathbf{X}$ & SD & t-cal & Remarks \\
\hline & 150 & 17.5 & 4.48 & \multirow{2}{*}{$1.16^{\circ}$} & \multirow{2}{*}{ NS } \\
\hline & 50 & 17.25 & 4.11 & & \\
\hline
\end{tabular}


Table 9. Independent t-test analysis to compare the mean ratings of registered crop beekeepers and extension agents on the educational requirements of beekeepers for mitigating climate change effects on bee honey production

\begin{tabular}{llllll}
\hline Group/variable & $\mathbf{N}$ & $\mathbf{X}$ & SD & t-cal & Remarks \\
\hline Registered beekeepers & 150 & 18.1 & 5.10 & \multirow{2}{*}{0.32} & NS \\
Extension agent & 50 & Significant at $0.05 ; \quad$ DF =198; critical t=1.960; & & \\
\hline & & $N S=N$ Not Significant
\end{tabular}

freedom. Since the calculated $t$-value was less than table value, the null hypothesis was upheld with the alternate hypothesis rejected. With this result, both respondents agreed that beekeepers required education on the five isolated items to be able to mitigate climate change effects in crop production in the study area.

\section{DISCUSSION}

Based on the hypothesis tested in this study, the findings were discussed under the following subheadings:

i. Ecological practices of beekeepers that contribute to climate change.

ii. Climate change and bee honey production,

iii. Educational Requirements of beekeepers in mitigating climate change effects in bee honey production.

\subsection{Ecological Practices of Beekeepers that Contribute to Climate Change}

The result of the test of hypothesis one revealed that respondents agreed that frequent ecological practices of beekeepers contribute to climate change effects. This finding agrees with [13] who stated that large number of ecological practices such as crop and animal production, fertilizer application, combustion of fossil fuel, biomass burning, deforestation among others produce gases which primarily contribute to climate change. The findings of this aspect of study is also supported by the statement of $[14,15,16]]$ who opined that climate change is mainly caused by the production of greenhouse gases from human activities including agricultural production, industrialization, burning of fossil and biofuels, and deforestation among others.

\subsection{Climate Change and Bee Honey Production}

The result of the test of hypothesis two revealed that climate change has impacted negatively on bee honey production in the study area. This finding agrees with $[17,18,19]$ who posited that climate change has adversely affected the stability of strong colonies and food security by bringing greater fluctuation in crop yields and local food supplies along with higher risks of landslides and erosion damage. Similarly, the findings of $[20,21,22,23]$ confirms with the submission that climate change results in some extreme weather events such heat waves, droughts, strong winds, heavy rains among others that detrimentally affect agricultural production. $[24,25]$ said that unavailability of water supply as a esult of climate change causes most of the nutrients in the soil which could be taken up by plants in soluble form to remain unutilized.

\subsection{Educational Requirements of Beekeepers in Mitigating Climate Change Effects in Bee Honey Production}

The result of hypothesis three of this study revealed that there is no significance difference in the mean ratings of registered beekeepers and extension agents on the educational requirements of beekeepers in mitigating climate change effects in bee honey production. The respondents unanimously agreed that beekeepers needed education on the isolated skill items in order to be proficient in mitigating climate change effects in crop production. This result is in line with [26] who stated that bee honey production practices plays tremendous role in mitigating climate change effects. Moreoso, the findings of this aspect of the study is also supported by the statement of [27] who stated that series of practices such as agroforestry, organic agriculture, zero or reduced tillage, cover cropping, intercropping, crop rotation, rice management, and farmingwith perennials offers climate change mitigative measures.

\section{CONCLUSION}

The purpose of this study was to determine the educational requirements of beekeepers for 
mitigating climate change effects in Obudu Local Government Area. Three hypothesis that were formulated and tested using independent t-test were all rejected. The rejection of this hypothesis is a pointer to the fact that:

i. Bee keepers in Obudu Local Government are often involve in isolated ecological practices which fuel climate change.

ii. Climate change due to these effect, has impacted on agricultural production in general and in honey production

iii. In the light of this development, bee farmers in the area now require education to mitigate climate change effects on crop production and honey.

Based on the findings of this study, the following conclusions are drawn:-

i. Ecological practices of beekeepers contribute to climate change.

ii. Climate change has significant effects on bee honey production.

iii. Beekeepers required education and training in order to be proficient in mitigating climate change effects in bee honey production.

Based on the findings and conclusion of this study, the following recommendations were made:

i. Beekeepers should not engage in ecological practices such as deforestation, biomass burning, soil tillage, clean clearing among others as they contribute primarily to climate change.

ii. Resistant crop varieties should be introduced to beekeepers by Agricultural Development Programme (ADP) in order to promote agricultural production.

iii. Agricultural Development Programme, Food and Agriculture organization, extension agents and other agricultural institutions should organize seminars and workshops to enlighten beekeepers on how to mitigate climate change effects in agricultural sector.

iv. Since climate change is a global issue that affects all sectors, public awareness should be made on radio, television, magazine, newsletters and other media to enlighten the general public on the causes, effects and mitigation strategies for ameliorating climate change.

\section{COMPETING INTERESTS}

Authors have declared that no competing interests exist.

\section{REFERENCES}

1. Adejuwon O. Experts Urge Action to stop Animal Diseases infecting Human. London: Cheston Agency Limited; 2006.

2. Markson PS. Climate change adaptation needs for food security. New York: Press and Books. 2004;320.

3. Parry : Global Climate change and US agriculture. London: Oxford University Press. 2007;123.

4. Ochiagha. Tropical Soils: Properties and management for sustainable agriculture. New York: Oxford University press. 2002;210.

5. IPCC. The Challenges of global warming Washington: Island Press. 2001;43.

6. IPCC. A Report of the Working Group of the Intergovernmental Paul on climate change summary for Policy makers. Geneva, Intergovernmental Panel in climate change; 2007.

7. Bernsky D. Economic Impact of Climate change on crop Production in Ethiopia: Evidence from cross-section measures. Journal of African Economies. 2007;(18) 4:529-554.

8. Hoenstein R. The implications of climate change for western agriculture. Rwanda: Macdow press; 2008.

9. Thomas CD, Cameroon A, Green R, Bakkenes M, Beamont LJ, Collingham YC. Extinction risk from climate change. Nature. 2004;427:145-148.

10. Royer RO. The social cost of climate change: Greenhouse damage and benefits of control. New York: McGraw-Hill Book. 2005;191.

11. FAO. Empirical Analysis of Agricultural Production and Climate change. Journal of Sustainable development in Nigeria. 2005;12(6).

12. FAO. The impacts of climate change in Africa: Final draft paper submitted to the stern Review on the Economics of climate change. 2001;2(1):23 -29.

13. Wuebbles $O$. Changes in surface water supply across African with predicted climate change. Washington: Hoxdell Publishers. 2002;132. 
14. Anderson PK. Impacts of climate variation on crop production. Enugu: Kraft Books; 2008.

15. Johnny HB. Climate change and Agricultural Vulnerability. Laxenburg: Totan Publishers; 2006.

16. Adrain W. An empirical study of the economic effects of climate change on world agriculture, Climate Change. 2009; 2(1):17-35

17. Mahfouf OP. Acidification and climate change. London: Kogan Ltd. 2002;150.

18. Ziesrmer E. Temperature rise and weather differences. Oweri: Totan Publishers. $2007 ; 212$.

19. Asuquo OP. Community based adaptation to climate change Bulletin. Uyo: University of Uyo Press; 2001.

20. Gbenga E. So/7 Maintenance Practices among beekeepers in Rural Communities: A case study of beekeepers in Anambra State. Akwa: Corporate printers. 2005; 34.

21. Howden W. Determinants of African beekeepers' strategies for adapting to climate change. Ibadan: Spring Publishers. 2002;56.

22. IPCC. Agroforestry Practices as adaptation tools to climate change Effects. Exploration Journal of Research On Climate Change. 2004;2(1):170- 176.

23. Moss O. Effects of climate change on water Resources in the Delaware River Basin. Water Resources Bulletin. 2000; 29(3):475-485.

24. Stein V. Government and Agriculture in Nigeria: Analysis of Polices, Programme and Administration. Ibadan: Macmillan Nigeria Publishers Limited. 2006;211.

25. Steinfeld L. Challenges to reduce. Greenhouse gas concentration in the atmosphere. London: Hodell and Penky Press. 2006;102.

26. Umanah SB. Ecological Practices and Climate variability. Uyo: University of Uyo Press; 2001.

27. Agbeda O. Analysis of climate change perception and Adaptation among Arable food crops in South. Climate Change. $2001 ; 3(4): 45$ - 50.

(c) 2019 Onabe et al.; This is an Open Access article distributed under the terms of the Creative Commons Attribution License (http://creativecommons.org/licenses/by/4.0), which permits unrestricted use, distribution, and reproduction in any medium, provided the original work is properly cited.

Peer-review history:

The peer review history for this paper can be accessed here: https://sdiarticle4.com/review-history/51528 